\section{Oncomouse released}

\section{Washington}

Du Pont announced last week that it is to begin selling transgenic mice carrying activated human cancer genes, or oncogenes. The mice were developed by Philip Leder of Harvard University and Timothy Stewart, now at Genentech, and were the first genetically altered animals to be patented. The patent, held by Harvard University, covers any transgenic non-human animal bearing an activated oncogene sequence introduced by genetic-engineering techniques.

The first 'oncomice' will carry the ras oncogene, which has been shown to be common in a variety of human cancers, plus a mouse mammary tumour virus promoter which ensures that the oncogene is activated in breast tissue so that the mice develop a human breast cancer within a few months of birth.

Du Pont says that oncomice will help speed the search for new drugs to treat cancer by allowing laboratories to test drugs against a human cancer in a animal. Pharmaceutical companies are likely to be the major purchasers. A price of $\$ 50-\$ 100$ per mouse seems likely, five to ten times that of an ordinary laboratory mouse. Later next year, Du Pont will offer mice bearing $m y c$ and neu oncogenes which are also found in human cancers.

But the sale of Du Pont's mice may be threatened by changes in government policy. Patent applications for more than twenty genetically engineered animals have been filed with the US Patent Office but animal rights activists are mounting an increasingly vociferous campaign to ban the patenting of genetically engineereed animals.

Alun Anderson

\section{Boston nets BASF}

\section{Munich}

THE chemical and pharmaceutical giant BASF AG announced on 11 November that a genetic engineering laboratory and pilot plant originally planned for West Germany will now be built in Boston. New regulations took effect in West Germany on 1 September, under which any production facility using genetically engineered organisms must be opened to the public for inspection before it can be approved. BASF anticipated objections from environmentalists and did not relish the idea of showing its design to the competition. Furthermore, the "climate for innovation" is better in Boston, said a spokesman, where there is a high concentration of experts in the field.

The complex is expected to cost DM100 million (about $\$ 60$ million) and to be completed in 1991. It will employ 60 scientists and 170 others in research and development in oncology and immunology. It was meant to be built at BASF headquarters in Ludwigshafen, near Heidelberg in southwest Germany.

\title{
Prospects for agreement on genetic resource issues
}

\section{Washington}

A BLUEPRINT for international action to preserve plant genetic resources emerged this week with the circulation of a draft document from a remarkable four-day international meeting held in Keystone, Colorado, in the summer. Although preservation of plant genetic resources is recognized as vital to the long-term health of the world's agriculture, attempts to coordinate efforts have been thwarted by competing international bureaucracies, and by divisive arguments between developed and developing countries.

The Keystone document represents a consensus that could cut a path through social and political complexities. The meeting organized by the Keystone Center in Colorado drew participants from all major concerned organizations, but encouraged them to speak as individuals. Only results that all could agree on were published.

The root of the problem is the fact that most of the world's naturally occurring genetic diversity for major crops exists in the developing world, but resources for breeding new crop lines or storing crop germplasm are in the developed world.

Proponents of 'farmers' rights' argue that plant breeders who use germplasm taken from primitive cultivated varieties ought to recompense the farmers who nurtered those seed lines for centuries. Developing countries doubt that genetic resources stored in banks in developed countries would be freely available.

Divisions between North and South also make it hard to decide who should be steering the international efforts to preserve plant genetic resources. In 1971, the World Bank established the Consultative Group on International Agriculture Research (CGIAR) which now acts as an umbrella organization for 13 international bodies, including the International Rice Research Organization in the Philippines and the Centro Internacional de Mejoramientio de Maiz y Trigo in Mexico. In 1974, another CGIAR body was established, the International Board on Plant Genetic Resources (IBPGR), with the aim of promoting worldwide conservation and utilization of plant genetic resources. IBPGR, like CGIAR, is run largely by the developed countries.

The Food and Agricultural Organization (FAO) of the United Nations is another major body interested in preserving genetic resources. In 1983, FAO established a new special Commission of Plant Genetic Resources. But several developed countries, notably the United States and Canada, declined to participate.

Several of the misconceptions barring progress may have been cleared away by the Keystone meeting. A key accomplishment, according to Pat Mooney of the Rural Advancement Fund International, an outspoken proponent of farmers' rights, is the new understanding on compensation. Although compensation is owed to farmers, Mooney says, he now believes it is understood that it is not necessary to pay each individual farmer whose seeds are used in the development of a new line.

To resolve the compensation issue, participants in the Keystone dialogue suggest an international fund to be administered by a global independent advisory committee, with members drawn from FAO, IBPGR, the International Union for the Conservation of Nature and Natural Resources (IUCN), non-governmental organizations and industry.

There was also progress on who should guide international resource management. Although the FAO commission was praised for the work it had accomplished, the Commission was urged to expand its membership to include all countries. Barring that, the dialogue paper suggested forming a joint United NationsFAO body that could report directly to both UN headquarters and FAO.

The report also urged that regional groups should become more involved in protecting resources, and that appropriate technologies be developed to make participation possible for the developing world.

Enthusiasm for the accomplishments of the Keystone dialogue is running high. M. S. Swaminathan, president of IUCN and chairman of the steering committee that organized the dialogue, says that considering the divergent opinions represented by the participants, the meeting went extremely well. Jose EsquinasAlcazar, secretary of the FAO commission says that the Keystone meeting was the first real opportunity for all the interested parties to work together.

Some have reservations about just how much was accomplished, however. John Holden, a member of the IGBPR board of trustees, says the group's goals were so broad that it may be difficult to implement them. Donald Duvick of Pioneer Hi-Bred International, says that clearing the air is important, but difficult problems of intellectual property rights remain.

The dialogue does at least look set to continue. Swaminathan says there are tentative plans for another meeting in Leningrad next year.

Joseph Palca

The final report of the Keystone International Dialogue Series on Plant Genetic Resources (August 15-18, 1988), is available from PO Box 606, Keystone, Colorado 80435, USA. 